\title{
Potencjał rozwoju rolnictwa i specjalizacja produkcji rolniczej w ujęciu regionalnym w świetle koncepcji specjalizacji inteligentnych w Polsce
}

\section{Potential of agriculture development and specialization of agricultural production in regional dimension in the context of smart specializations in Poland}

\author{
Damian MAZUREK \\ Instytut Geografii i Przestrzennego Zagospodarowania PAN \\ ul. Twarda 51/55, 00-818 Warszawa \\ d.mazurek@twarda.pan.pl
}

\begin{abstract}
Zarys treści: $W$ artykule przedstawiono analizę potencjału rozwoju sektora rolnego w Polsce $w$ ujęciu regionalnym w świetle koncepcji specjalizacji inteligentnych. Dokonano analizy dokumentów strategicznych na szczeblu regionalnym pod kątem specjalizacji inteligentnych. Przeanalizowano 3 potencjały: gospodarczy, naturalny i naukowo-badawczy. Ponadto dokonano analizy specjalizacji produkcyjnych w każdym z regionów pod kątem profilu produkcji, jak też liczby kierunków produkcji rolnej. W artykule dokonano także syntetycznej oceny potencjałów rozwoju w kontekście wdrażania poszczególnych regionalnych specjalizacji inteligentnych. Cele Strategii Europa 2020 rozszerzają politykę regionalną o wypracowanie Regionalnych Strategii Innowacji, w ramach których regiony zobligowane są do zidentyfikowania swoich mocnych stron. Ma to duże znaczenie w kontekście nowego programu finansowania w latach 2014-2020, gdyż wspierane w ramach RSI inicjatywy mają wdrożyć województwa w innowacyjny model rozwoju gospodarczego. Jednakże wybór inteligentnej specjalizacji nie zawsze odzwierciedla rzeczywisty potencjał regionu w danym sektorze. Sektor rolnictwa jest ponadto specyficzny ze względu na wiele uwarunkowań, przez co potencjał produkcji ogółem jest mało porównywalny między regionami.
\end{abstract}

Słowa kluczowe: specjalizacja inteligentna, potencjał rozwoju, specjalizacja produkcji rolniczej, rozwój rolnictwa, Regionalna Strategia Innowacji.

\section{Wstęp}

Rozwój obszarów wiejskich w świetle polityki Unii Europejskiej jest oparty na funduszach strukturalnych, w ramach których beneficjenci finansują różne przedsięwzięcia adekwatnie do stawianych celów strategicznych. Finansowanie rozwoju na obszarach wiejskich odbywało się dotychczas przede wszystkim głównym strumieniem, jakim jest Program Rozwoju Obszarów Wiejskich (PROW), jednakże w obecnie prowadzonej polityce regionalnej UE obszary te mogą także partycypować w funduszach wspierających inicjatywy innowacyjne w ramach Strategii Europa 2020 poprzez Europejski Fundusz Spójności (EFS) 
i Europejski Fundusz Rozwoju Regionalnego (EFRR). Celem artykułu jest weryfikacja specjalizacji inteligentnych związanych z działalnością rolniczą, wskazanych w dokumentach strategicznych pod kątem rzeczywistego potencjału rozwoju rolnictwa w ujęciu regionalnym. Dokonano syntetycznej oceny potencjałów rozwoju. Specyfika specjalizacji inteligentnej wymaga jednak szerszego podejścia do analizy rolnictwa. Podjęto więc próbę identyfikacji specjalizacji produkcyjnej w każdym z województw oraz analizy liczby kierunków produkcji.

Środki na realizację celów polityki rolnej pochodzą z Europejskiego Funduszu Rolnego na rzecz Rozwoju Obszarów Wiejskich (EFRROW). Cele polityki kraju w tym zakresie nawiązują do celów Strategii Europa 2020, a więc dotyczą poprawy konkurencyjności rolnictwa, zrównoważonego zarządzania zasobami naturalnymi oraz zrównoważonego rozwoju terytorialnego obszarów wiejskich (www.minrol.gov.pl, 07.04.2017). Polska w ostatnich latach (1999-2006) przeszła fazę reform na poziomie lokalnym i regionalnym oraz wdrożenie polskich regionów w politykę spójności UE (2007-2013). Obecnie (2014-2020) znajdujemy się w fazie realizacji rozwoju zrównoważonego i rozwoju inteligentnego (Ślusarz 2015).

Koncepcja specjalizacji inteligentnych jest ukierunkowana na rozwój mocnych stron regionu, pomijając słabe strony, które do tej pory były istotnym elementem strategicznego planowania i dystrybucji środków finansowych (Benner 2013). Jak zauważają H. Bathelt i J. Glückler (2012), polityka Unii ukierunkowuje się na wykorzystanie instrumentów prorozwojowych. D. Foray (2009) oraz M. Benner (2013) zwracają uwagę, że specjalizacje inteligentne nie powinny być tylko kontynuacją dotychczasowej polityki UE, lecz świadczyć też o spójności polityki w zakresie celów Strategii Europa 2020 (Benner 2013). Powinna następować kohezja w wyniku wdrażania koncepcji specjalizacji inteligentnych (Foray 2009), gdyż dzięki tej koncepcji może być zapewniony rozwój zrównoważony, np. poprzez rozwój zielonych technologii oraz inclusive growth poprzez inwestowanie w innowacje społeczne, wykorzystanie kapitału społecznego, zmiany strukturalne i wzmacnianie spójności terytorialnej.

Pojęcie specjalizacji inteligentnej zostało wypracowane przez grupę ekspercką „Wiedza dla wzrostu”, a jej głównym zwolennikiem był prof. D. Foray. Specjalizacja inteligentna jest specjalizacją regionalną, tworzoną przez sektory gospodarki dominujące w strukturze gospodarczej danego regionu lub te, które są uznawane za najbardziej konkurencyjne. Na specjalizację inteligentną, w odróżnieniu od specjalizacji produkcyjnej (starter gospodarczy), składają się również sfera badawcza i sfera wiedzy (knowhow), technologie ogólnego zastosowania (GPT - General Purpose Technologies) oraz nowe innowacyjne technologie (Kardas 2011; Dzierżanowski 2013; Dziemianowicz i in. 2014). Szczególną wagę w tej koncepcji przypisuje się innowacji jako niezbędnemu czynnikowi kształtującemu konkurencyjność regionu w danym sektorze gospodarki (Dzierżanowski 2013). Zwiększana jest w tym procesie także rola państwa, gdyż istotne jest tworzenie przestrzeni dla badań i innowacji (interwencjonizm) w ramach procesu specjalizowania się (Foray 2009). Według M. Kardasa (2011) i T.G. Grosse (2002) ważna jest dywersyfikacja gospodarki, co w świetle teorii produktu podstawowego (staple theory) Innesa czy teorii bazy ekonomicznej (economic base theory), staje się stwierdzeniem nie do końca zgodnym z pojęciem specjalizacji regionalnej. Specjalizacje inteligentne mogą obejmować więcej niż jeden sektor. Istnieją dwa podejścia w ich identyfikacji. Pierwsze - oparte na starym paradygmacie polityki rozwoju regionalnego - polega na podejściu sektorowym w kwestii 
identyfikacji mocnych stron regionu. Drugie, nowsze podejście - projektowe - pozwala w sposób zintegrowany i wielopłaszczyznowy wskazać specjalizacje, bazując na współpracy z otoczeniem, które dana specjalizacja obejmuje (Vanthillo i Verhetsel 2012).

Specjalizowanie się jest to - jak podkreśla D. Foray (2009) - ciągły proces przedsiębiorczego uczenia się (entrepreneurial learning process). Koncepcja specjalizacji inteligentnych w swych założeniach przypomina koncepcją klastra M.E. Portera (1990), czyli grupy przedsiębiorstw konkurujących i współpracujących ze sobą na obszarze tych samych lub pokrewnych sektorów gospodarki, powiązanych z instytucjami wspierającymi ich działalność. Klaster, podobnie jak w założeniach specjalizacja inteligentna, tworzy i wprowadza na rynek innowacje, jest konkurencyjny i prorozwojowy (Rehfeld 2013; Benner 2013; Kardas 2011).

Klastrami mogą być regiony specjalizujące się w produkcji rolniczej. Problematyczne okazuje się jednak zmierzenie specjalizacji produkcyjnej rolnictwa. R. Kulikowski (2003, s. 98) definiuje specjalizację rolnictwa jako „proces ciągły polegający na ograniczaniu liczby produktów z jednoczesnym doskonaleniem ich wytwarzania”. Miarą specjalizacji rolnictwa według tego autora jest towarowość rolnictwa. Badania nad stopniem specjalizacji rolnictwa prowadzone przez J. Okuniewskiego (1958, 1959), Z. Wojtaszka (1963) oraz W. Pytkowskiego (1964) dotyczyły specjalizacji gospodarstw rolnych. Autorzy zastanawiali się wówczas, jak zmierzyć stopień specjalizacji. Brano pod uwagę udziały w produkcji gałęzi oraz liczbę działalności w poszczególnych gospodarstwach. W latach 60. posługiwano się także liczbą uprawianych roślin, ilością produktów rolnych i hodowanych zwierząt (Kulikowski 2003). Stosowane metody nie pozwalały jednak badać jednostek większych niż gospodarstwo i przy większych jednostkach terytorialnych, jak gmina czy powiat, osiągane wyniki stawały się mniej obiektywne. Jedną z pierwszych prób zbadania specjalizacji regionalnej podjął I.R. Bowler (1986, 1987).

Badania nad specjalizacją produkcyjną rolnictwa, określaną także mianem towarowości, prowadzili J. Szyrmer $(1975,1980)$ i R. Kulikowski $(2003,2012)$. Istotną problematykę podjął także J. Bański (1999) w pracy Obszary problemowe w rolnictwie Polski, w której wyodrębnił obszary rezerw produkcyjnych - obszarów o wysokim, lecz niewykorzystywanym potencjale produkcyjnym oraz dokonał typologii rolniczych obszarów problemowych w Polsce. Próbę zbadania specjalizacji produkcyjnej w ujęciu regionalnym, stosując indeks Krugmana, podjęła A. Tłuczak (2016).

W artykule dokonano analizy dokumentów strategicznych pod kątem słów kluczowych i zestawiono te specjalizacje, które w swoim profilu obejmują sektor rolnictwa (tab. 1). Pozostałych specjalizacji - z uwagi na brak powiązań z rolnictwem - nie uwzględniono w badaniu i nie zestawiono ich w tabeli poniżej. Należy zaznaczyć, że jedna specjalizacja może zaliczać się do więcej niż jednej kategorii. Dwa województwa (kujawsko-pomorskie i podlaskie) wybrały po 2 specjalizacje związane z rolnictwem. Województwa śląskie i pomorskie nie wskazały żadnej specjalizacji powiązanej z tym sektorem. Specjalizacje w większości mają wieloaspektowy charakter i ich nazwy często nie wskazują na powiązania z sektorem rolnictwa. Część specjalizacji ma charakter sektorowy i dotyczy produkcji żywności lub przetwórstwa rolno-spożywczego. Niektóre jednak mają szerszy zakres, jak np. ekoinnowacje, nauki o środowisku i sektory powiązane z nimi łańcuchem wartości czy biogospodarka. 
Tabela 1. Specjalizacje inteligentne województw (wybrane wg powiązań z sektorem rolnictwa; stan na 22.06.2017)

\begin{tabular}{|c|c|c|}
\hline Województwo & Specjalizacja inteligentna & Źródło \\
\hline Dolnośląskie & żywność wysokiej jakości & $\begin{array}{l}\text { Ramy Strategiczne Na Rzecz Inteligent- } \\
\text { nych Specjalizacji Dolnego Ślq̨ska, } 2015\end{array}$ \\
\hline \multirow{2}{*}{ Kujawsko-pomorskie } & $\begin{array}{l}\text { najlepsza bezpieczna żywność -prze- } \\
\text { twórstwo, nawozy i opakowania }\end{array}$ & \multirow{2}{*}{$\begin{array}{l}\text { Załacznik nr } 5 \text { do Regionalnych Spe- } \\
\text { cjalizacji Inteligentnych Województwa } \\
\text { Kujawsko-Pomorskiego 2014-2020 }\end{array}$} \\
\hline & $\begin{array}{l}\text { biointeligentna specjalizacja - potencjał } \\
\text { naturalny, środowisko, energetyka }\end{array}$ & \\
\hline Lubelskie & biogospodarka & $\begin{array}{l}\text { Załacznik nr } 11 \text { do Regulaminu konkursu } \\
\text { - Indykatywna lista kodów PKD wpisu- } \\
\text { jacych się w Regionalne Inteligentne } \\
\text { Specjalizacje Województwa Lubelskiego }\end{array}$ \\
\hline Lubuskie & zdrowie i jakość życia & $\begin{array}{l}\text { Obszary Inteligentnych Specjalizacji } \\
\text { Województwa Lubuskiego, } 2014\end{array}$ \\
\hline Łódzkie & $\begin{array}{l}\text { innowacyjne rolnictwo i przemysł } \\
\text { rolno-spożywczy }\end{array}$ & $\begin{array}{l}\text { Wykaz Regionalnych Inteligentnych } \\
\text { Specjalizacji Województwa Łódzkiego } \\
\text { oraz wynikajacych z nich nisz specjaliza- } \\
\text { cyjnych, } 2015\end{array}$ \\
\hline Małopolskie & nauki o życiu (Life sciences) & $\begin{array}{l}\text { Inteligentne Specjalizacje Województwa } \\
\text { Małopolskiego: uszczegółowienie obsza- } \\
\text { rów wskazanych w RSI WM 2014-2020, } \\
2015\end{array}$ \\
\hline Mazowieckie & bezpieczna żywność & $\begin{array}{l}\text { Regionalna Strategia Innowacji dla } \\
\text { Mazowsza do } 2020 \text { roku, } 2015\end{array}$ \\
\hline Opolskie & technologie rolno-spożywcze & $\begin{array}{l}\text { http://rpo.ocrg.opolskie.pl/aktualnosc- } \\
\text {-75-specjalizacje_inteligentne_woje- } \\
\text { wodztwa.html }\end{array}$ \\
\hline Podkarpackie & jakość życia & $\begin{array}{l}\text { Wiodqce branże województwa podkar- } \\
\text { packiego - inteligentne specjalizacje } \\
\text { regionalne, } 2014\end{array}$ \\
\hline \multirow[b]{2}{*}{ Podlaskie } & $\begin{array}{l}\text { sektor rolno-spożywczy i sektory powią- } \\
\text { zane z nim łańcuchem wartości }\end{array}$ & \multirow{2}{*}{$\begin{array}{l}\text { Plan rozwoju przedsiębiorczości } \\
\text { w oparciu o inteligentne specjalizacje } \\
\text { województwa podlaskiego na lata } \\
2015-2020+(R / S 3), 2015\end{array}$} \\
\hline & $\begin{array}{l}\text { ekoinnowacje, nauki o środowisku } \\
\text { i sektory powiązane z nimi łańcuchem } \\
\text { wartości }\end{array}$ & \\
\hline Świętokrzyskie & $\begin{array}{l}\text { nowoczesne rolnictwo i przetwórstwo } \\
\text { spożywcze }\end{array}$ & $\begin{array}{l}\text { Załacznik nr } 1 \text { do Planu Wykonawczego } \\
\text { do RIS3 }\end{array}$ \\
\hline Warmińsko-mazurskie & żywność wysokiej jakości & $\begin{array}{l}\text { Badanie potencjału innowacyjne- } \\
\text { go i rozwojowego przedsiębiorstw } \\
\text { funkcjonujqcych w obszarze inteli- } \\
\text { gentnych specjalizacji województwa } \\
\text { warmińsko-mazurskiego }\end{array}$ \\
\hline Wielkopolskie & $\begin{array}{l}\text { biosurowce i żywność dla świadomych } \\
\text { konsumentów }\end{array}$ & $\begin{array}{l}\text { http://iw.org.pl/ } \\
\text { obszary-inteligentnych-specjalizacji/ }\end{array}$ \\
\hline Zachodniopomorskie & $\begin{array}{l}\text { nowoczesne przetwórstwo } \\
\text { rolno-spożywcze }\end{array}$ & $\begin{array}{l}\text { Wykaz inteligentnych specjalizacji } \\
\text { województwa zachodniopomorskiego } \\
\text { (Projekt), } 2016\end{array}$ \\
\hline
\end{tabular}

Źródło: opracowanie własne. 
Udział liczby specjalizacji inteligentnych w Polsce związanych z sektorem rolnictwa wynosi 14\% (ryc. 1). Biorąc pod uwagę mnogość gałęzi przemysłu i traktując każdą z nich osobno, sektor rolnictwa jest najczęściej reprezentowany spośród wszystkich sektorów w dokumentach RSI.

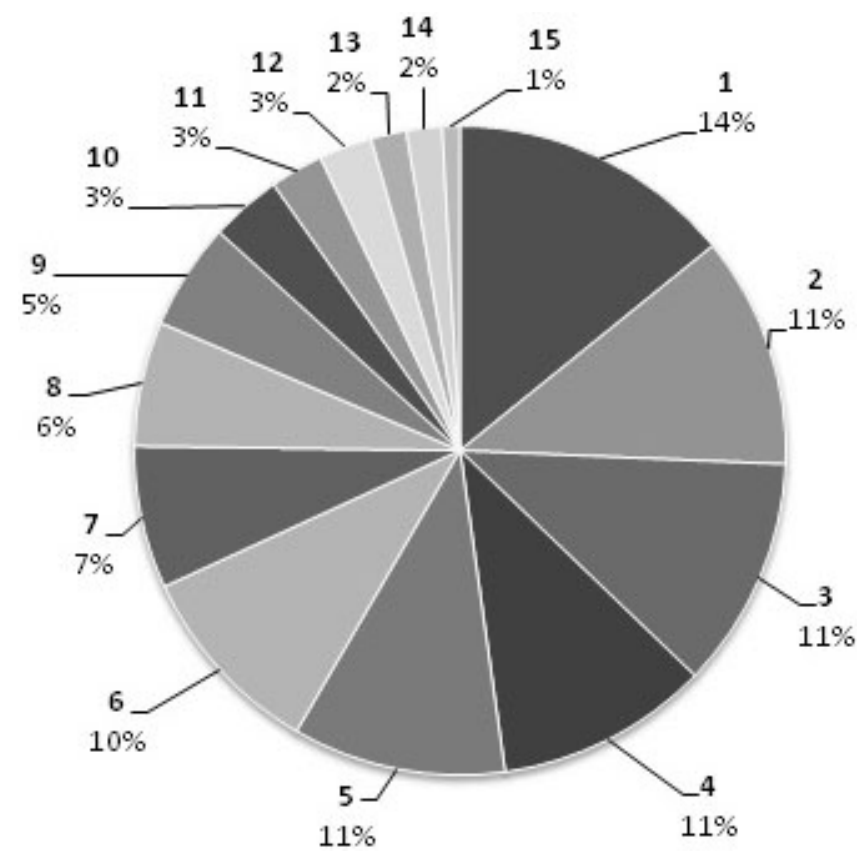

Ryc. 1. Struktura specjalizacji inteligentnych wg autorskiego podziału na kategorie

1 - rolnictwo (agriculture), 2 - technologie informacyjno-komunikacyjne (information and communication technologies), 3 - energetyka i przemysł wydobywczy (power industry and mining industry), 4 - przemysł maszynowy, elektromaszynowy, metalowy, motoryzacyjny (machinery industry, electromechanical industry, metal industry, automotive industry), 5 - ekologia (ecology), 6-medycyna (medicine), 7 - chemia i tworzywa sztuczne (chemistry and plastics), 8- przemysł drzewny i meblarstwo (wood industry and furniture production), 9- budownictwo (civil engineering), 10 - usługi biznesowe (business services), 11 - transport lądowy i logistyka (land transport and logistics), 12 - transport morski i logistyka (maritime transport and logistics), 13 - potrzeby społeczne i jakość życia (social needs and quality of life), 14 - dziedzictwo kulturowe (cultural heritage), 15 - przemysł włókienniczy (textile industry).

Źródło: opracowanie własne na podstawie dokumentów z tabeli 1.

Source: own elaboration based on documents in Table 1.

\section{Metodologia}

Metodologia identyfikacji specjalizacji inteligentnych jest niespójna w poszczególnych dokumentach na szczeblu regionalnym, co utrudnia ich zbadanie. Ponadto, zależność od wielu czynników, takich jak: struktura agrarna, stopień mechanizacji, warunki naturalne nie ułatwiają zbadania specjalizacji inteligentnych związanych z sektorem rolnictwa. Problematyczne jest zmierzenie poziomu rozwoju danego sektora pod kątem konkretnej specjalizacji. Rozwój inteligentny oparty na procesach „przedsiębiorczego uczenia się”, o którym pisali A. Rodriguez-Pose (2001), B. Bilbao-Osorio i A. Rodriguez-Pose (2004), D. Foray (2009), F. Barca i in. (2012) oraz P. McCann i R. Ortega-Argilés, (2013), jest niepo- 
liczalny (Naldi i in. 2015). W niniejszym artykule nie podjęto więc z przyczyn obiektywnych próby analizy szeroko pojętego „rozwoju inteligentnego”. Przeanalizowano natomiast potencjały rozwojowe oraz dokonano identyfikacji specjalizacji produkcyjnej w celu wykazania, że specjalizacje inteligentne w różnych województwach mogą mieć zupełnie inny charakter właśnie ze względu na różny profil produkcji rolnej. Analiza potencjałów pozwoliła określić, które specjalizacje inteligentne zostały wskazane zgodnie z rzeczywistym potencjałem rozwoju.

Podstawowym czynnikiem identyfikacji danej specjalizacji jest potencjał endogeniczny. Charakter specjalizacji inteligentnych, które opierają się na GPT i potencjale naukowo-badawczym, implikuje podział badania sektora rolnictwa na analizę potencjałów: gospodarczego, naturalnego i naukowo-badawczego (tab. 2).

Tabela 2. Wskaźniki potencjałów przyjęte w badaniu

\begin{tabular}{|l|l|}
\hline $\begin{array}{l}\text { Potencjał } \\
\text { gospodarczy }\end{array}$ & $\begin{array}{l}\text { - udział liczby podmiotów (PKD 2007): sekcja A dział } 01 \text { w liczbie podmiotów ogółem (2015) } \\
\text {-udział liczby podmiotów (PKD 2007): sekcja C dział } 10 \text { w liczbie podmiotów ogółem (2015) } \\
\text { - liczba traktorów o mocy powyżej 60kW/1ha użytków rolnych (2016) }\end{array}$ \\
\hline $\begin{array}{l}\text { Potencjał } \\
\text { naturalny }\end{array}$ & - wskaźnik jakości rolniczej przestrzeni produkcyjnej (2010 \\
\hline $\begin{array}{l}\text { Potencjał nauko- } \\
\text { wo-badawczy }\end{array}$ & $\begin{array}{l}\text { - liczba absolwentów po studiach rolniczych/1000 absolwentów ogółem (2015) } \\
\text { - nakłady wewnętrzne na działalność B+R w dziedzinie nauk rolniczych w zł (2015) }\end{array}$ \\
\hline
\end{tabular}

Źródło: opracowanie własne.

Potencjał gospodarczy został obliczony na podstawie danych o podmiotach gospodarczych w sekcji A dział 01 (uprawy rolne, chów i hodowla zwierząt, łowiectwo, włączając działalność usługową) i sekcji C dział 10 (produkcja artykułów spożywczych), danych o produkcji towarowej oraz stopniu mechanizacji z wyszczególnieniem ciągników o wysokiej mocy silnika. Poprzez potencjał gospodarczy rolnictwa rozumie się zdolność do ekonomicznej (efektywnej) produkcji rolniczej, dlatego też przyjęty zestaw wskaźników powinien wykazać, które województwa posiadają odpowiednią bazę ekonomiczną do produkcji i przetwórstwa produktów rolnych.

W analizie potencjału naturalnego posłużono się wskaźnikiem jakości rolniczej przestrzeni produkcyjnej (wjrpp). Waloryzacji rolniczej przestrzeni produkcyjnej dokonano na podstawie wskaźników bonitacji: jakości i przydatności rolniczej gleb, agroklimatu, rzeźby terenu i warunków wodnych (Raport... 2010).

Potencjał naukowo-badawczy jest istotnym elementem specjalizacji inteligentnej. Inteligentny rozwój powinien opierać się na zaawansowanych technologiach i badaniach, dlatego też w analizie uwzględniono wydatki na sektor $B+R$ w rolnictwie oraz liczbę absolwentów uczelni wyższych o profilu rolniczym w przeliczeniu na 1000 absolwentów ogółem.

Wielowymiarowe analizy taksonomiczne (Pluta 1977) umożliwiają zestawienie danych ilościowych, które mają różne jednostki miary i obliczenie wskaźnika syntetycznego oraz odległości od wzorca poprzez standaryzację tych danych. Metodę wielowymiarowej analizy porównawczej wykorzystano w analizie potencjałów rozwoju rolnictwa. Procedura obliczeniowa przedstawia się następująco: 
Standaryzacja danych:

$$
\begin{aligned}
& y_{S}^{\prime}=\frac{y_{i j}}{\max y_{i j}}, \quad j^{\prime} \in S, j=1,2, \ldots, n \\
& y_{D}^{\prime}=\frac{\min y_{i j}}{y_{i j}}, \quad j^{\prime} \in D, j=1,2, \ldots, m
\end{aligned}
$$

gdzie:

$y_{S}^{\prime}-$ wartość stymulanty po standaryzacji

$y_{D}^{\prime}$ - wartość destymualnty po standaryzacji

$y_{i j}$ - wartość wskaźnika w j-tej jednostce przestrzennej

max $y_{i j}$ - najwyższa wartość wskaźnika

$\min y_{i j}$ - najniższa wartość wskaźnika

Obliczanie wskaźnika sumarycznego:

$$
S_{i}=\sum_{j}^{n} y_{S}^{\prime}+\sum_{j=1}^{m} y_{D}^{\prime}
$$

Obliczanie wskaźnika sumarycznego unormowanego:

$$
S_{i}^{n}=\frac{\sum_{j}^{n} y_{S}^{\prime}+\sum_{j=1}^{m} y^{\prime}{ }_{D}}{n+m}
$$

gdzie:

$n+m-$ liczba stymulant i destymulant.

Kolejnym etapem analizy była synteza osiągniętych wyników. Przyjęto, że wartością progową będzie średnia arytmetyczna wskaźników sumarycznych unormowanych poszczególnych potencjałów:

$$
W P=\frac{\sum S_{i}^{n}}{16}
$$

gdzie:

WP - wartość progowa

Następnie dokonano klasyfikacji:

$S_{i}^{n}>$ WP -1 pkt

$S_{i}^{n}<\mathrm{WP}-0 \mathrm{pkt}$

W kolejnym kroku dokonano zsumowania uzyskanych punktów i wydzielono następujące klasy:

3 pkt - wysoki potencjał (rozwoju) specjalizacji

2 pkt - średni potencjał specjalizacji

1 pkt - niski potencjał specjalizacji

0 pkt - brak potencjału

W badaniach nad specjalizacją produkcji rolniczej wykorzystywano wskaźnik specjalizacji rolniczej zaproponowany przez J. Kostrowickiego (Szyrmer 1975). Metoda ta polega na obliczeniu stopnia specjalizacji przy użyciu danych ilościowych w postaci wielkości produkcji rolniczej mierzonej w tej samej jednostce miary, np. w decytonach (wzór poni- 
żej). W ten sposób można stwierdzić, który profil produkcji dominuje w poszczególnych regionach - w czym dany region się specjalizuje. Jednakże ze względu na konstrukcję tego wskaźnika, dane te nie są porównywalne między regionami, gdyż nie świadczą o większej produkcji w regionach wyspecjalizowanych w porównaniu z tymi mniej wyspecjalizowanymi.

$$
\begin{gathered}
W_{j}=\sqrt{\sum_{i=1}^{m} a_{i j}^{2}} \\
\frac{1}{\sqrt{m}} \leq W_{j} \leq 1
\end{gathered}
$$

gdzie:

$m$ - liczba cech,

$\sum_{i=1}^{m} a_{i j}^{2}$ - suma kwadratów j-tych cech w i-tej w jednostce terytorialnej.

Analizę specjalizacji produkcyjnej poddano syntezie. Wysokość stopnia specjalizacji produkcyjnej postanowiono sklasyfikować według metody średnich zagnieżdżonych. Celem badania było wskazanie regionów o wybitnej specjalizacji produkcyjnej. W pierwszym etapie obliczona została średnia arytmetyczna (sr2) dla danego zbioru wartości, w tym przypadku dla danego profilu produkcji. Następnie obliczono średnie arytmetyczne (kolejno sr1 i sr3) dla wartości poniżej średniej oraz osobno dla wartości powyżej średniej obliczonej w pierwszym etapie. W ten sposób otrzymano 4 stopnie specjalizacji produkcji:

- wybitny - powyżej sr3,

- wysoki-sr2-sr3,

- przeciętny-sr1-sr2,

- niski - poniżej sr1.

Z merytorycznego punktu widzenia istotne jest wyodrębnienie produkcji zwierzęcej i roślinnej. W badaniach nad specjalizacją produkcyjną wskaźnik specjalizacji często obliczany jest przy wykorzystaniu wszystkich danych - zarówno dla produkcji zwierzęcej, jak i roślinnej. Nie jest to do końca poprawne podejście ze względu na odmienną charakterystykę danych (np. wartość w dt żywca wieprzowego w stosunku do zbiorów pszenicy w dt). Dlatego też w niniejszym artykule oba rodzaje produkcji potraktowane są osobno.

W produkcji zwierzęcej uwzględniono: żywiec wieprzowy, barani, drobiowy, cielęcy i wołowy. Ponadto obliczono udział w kraju w produkcji mleka krowiego każdego z województw. W produkcji roślinnej uwzględniono: a) owoce jagodowe, warzywa gruntowe, owoce z drzew oraz osobno: b) zboża podstawowe z mieszankami, ziemniaki, buraki cukrowe, rzepak i rzepik oraz produkcję siana z łąk i pastwisk łącznie.

W części analitycznej dotyczącej specjalizacji produkcyjnej przedstawiono także kierunki specjalizacji produkcyjnej (towarowości). Wyniki uzyskano przy zastosowaniu metody Okuniewskiego (1958, 1959), według której wydzielono gałęzie produkcji, które w danym regionie dominują:

- udział w produkcji powyżej 50\% - specjalizacja jednokierunkowa,

- udział 2 gałęzi produkcji łącznie wyższy niż 50\% (przy założeniu że udział każdej z nich nie przekraczał 50\%) - specjalizacja dwukierunkowa,

- udział w produkcji poniżej 50\% - brak specjalizacji. 
Produkcję mleka potraktowano osobno ze względu na wysoki poziom produkcji w każdym z województw. W tym przypadku decydowała średnia wielkość produkcji. W przypadku wybitnej specjalizacji, profil ten został uwzględniony w produkcji zwierzęcej jako dodatkowy kierunek.

\section{Analiza potencjałów rozwojowych}

Badanie potencjału gospodarczego pokazuje zdecydowaną przewagę województwa wielkopolskiego. Nieco niższe wartości osiągnęły województwa mazowieckie i lubelskie, które dysponują także wysokim potencjałem gospodarczym (tab. 3). Najsłabiej pod tym względem wypadają województwa: śląskie, podkarpackie, dolnośląskie, lubuskie, małopolskie, pomorskie, świętokrzyskie i zachodniopomorskie.

Tabela 3. Potencjały rozwojowe - wskaźniki sumaryczne unormowane

\begin{tabular}{|l|c|c|c|}
\hline \multirow{2}{*}{ Województwo } & \multicolumn{3}{|c|}{ Wskaźnik sumaryczny unormowany } \\
\cline { 2 - 4 } & gospodarczy & naturalny & naukowo-badawczy \\
\hline Dolnośląskie & 0,41 & 0,92 & 0,31 \\
Kujawsko-pomorskie & 0,65 & 0,87 & 0,26 \\
Lubelskie & 0,71 & 0,91 & 0,67 \\
Lubuskie & 0,43 & 0,77 & 0,06 \\
tódzkie & 0,64 & 0,76 & 0,15 \\
Małopolskie & 0,41 & 0,85 & 0,39 \\
Mazowieckie & 0,75 & 0,74 & 0,71 \\
Opolskie & 0,54 & 1,00 & 0,02 \\
Podkarpackie & 0,38 & 0,86 & 0,14 \\
Podlaskie & 0,65 & 0,68 & 0,12 \\
Pomorskie & 0,40 & 0,81 & 0,02 \\
Śląskie & 0,36 & 0,79 & 0,02 \\
Świętokrzyskie & 0,43 & 0,85 & 0,00 \\
Warmińsko-mazurskie & 0,59 & 0,81 & 0,67 \\
Wielkopolskie & 0,96 & 0,80 & 0,58 \\
Zachodniopomorskie & 0,45 & 0,83 & 0,15 \\
\hline Średnia (WP) & 0,55 & 0,83 & 0,27 \\
\hline
\end{tabular}

Źródło: opracowanie własne.

W analizie wskaźnika potencjału naturalnego wartości powyżej średniej osiągnęły województwa: dolnośląskie, kujawsko-pomorskie, lubelskie, małopolskie, opolskie, podkarpackie, świętokrzyskie oraz zachodniopomorskie. Najsłabiej, przede wszystkim ze względu na jakość i przydatność rolniczą gleb, agroklimat oraz warunki wodne, wypadają województwa: podlaskie, mazowieckie i lubuskie (Raport... 2010).

Z analiz potencjału naukowo-badawczego wynika duża rozbieżność uzyskanych wyników $(0,00-0,71)$. Widoczny jest wpływ renomowanych uczelni wyższych oraz możliwości 
finansowych województw. Najwyższe wskaźniki osiągnęły województwa: mazowieckie, warmińsko-mazurskie, lubelskie oraz wielkopolskie.

Analiza potencjałów rozwoju rolnictwa potwierdziła zasadność wyboru specjalizacji inteligentnych związanych z tym sektorem w kilku województwach: lubelskim (potencjał wysoki), dolnośląskim, kujawsko-pomorskim, małopolskim, mazowieckim, warmińsko-mazurskim i wielkopolskim (potencjał średni). W województwie lubelskim zidentyfikowano 1 specjalizację związaną z sektorem rolnictwa. 6 województw osiągnęło średni poziom potencjału. W przypadku województw: dolnośląskiego i małopolskiego występują niewystarczające warunki gospodarcze do rozwoju specjalizacji inteligentnych. Województwa mazowieckie, warmińsko-mazurskie i wielkopolskie dysponują słabszymi warunkami naturalnymi, natomiast województwo kujawsko-pomorskie odstaje od pozostałych pod kątem zaplecza naukowo-badawczego. W tych województwach samorządy wskazały od 1 do 2 specjalizacji inteligentnych związanych z rolnictwem. Tyle samo województw osiągnęło niski poziom potencjału i także w tych województwach wskazano od 1 do 2 specjalizacji. Brak potencjału rozwoju rolnictwa stwierdzono w województwie lubuskim (1 specjalizacja) oraz pomorskim i śląskim, gdzie samorządy nie wskazały żadnej specjalizacji inteligentnej związanej z sektorem rolnictwa (tab. 4).

Tabela 4. Analiza potencjałów rozwoju rolnictwa - synteza

\begin{tabular}{|c|c|c|c|c|c|c|}
\hline Województwo & Liczba IS & $\begin{array}{c}\text { Potencjał } \\
\text { gospodar- } \\
\text { czy }\end{array}$ & $\begin{array}{l}\text { Potencjał } \\
\text { naturalny }\end{array}$ & $\begin{array}{l}\text { Potencjał } \\
\text { naukowo- } \\
\text {-badawczy }\end{array}$ & $\begin{array}{c}\text { Suma } \\
\text { punktów }\end{array}$ & $\begin{array}{c}\text { Syntetycz- } \\
\text { na ocena } \\
\text { potencjału }\end{array}$ \\
\hline Lubelskie & 1 & 1 & 1 & 1 & 3 & wysoki \\
\hline Kujawsko-pomorskie & 2 & 1 & 1 & & 2 & średni \\
\hline Mazowieckie & 1 & 1 & & 1 & 2 & średni \\
\hline Warmińsko-mazurskie & 1 & 1 & & 1 & 2 & średni \\
\hline Wielkopolskie & 1 & 1 & & 1 & 2 & średni \\
\hline Dolnośląskie & 1 & & 1 & 1 & 2 & średni \\
\hline Małopolskie & 1 & & 1 & 1 & 2 & średni \\
\hline Łódzkie & 1 & 1 & & & 1 & niski \\
\hline Podlaskie & 2 & 1 & & & 1 & niski \\
\hline Opolskie & 1 & & 1 & & 1 & niski \\
\hline Podkarpackie & 1 & & 1 & & 1 & niski \\
\hline Świętokrzyskie & 1 & & 1 & & 1 & niski \\
\hline Zachodniopomorskie & 1 & & 1 & & 1 & niski \\
\hline Lubuskie & 1 & & & & & brak \\
\hline Pomorskie & 0 & & & & & brak \\
\hline Śląskie & 0 & & & & & brak \\
\hline
\end{tabular}

Źródło: opracowanie własne. 


\section{Identyfikacja i analiza specjalizacji produkcyjnych}

Kolejnym etapem badania jest identyfikacja specjalizacji produkcyjnej. Według przyjętej metody (średnich zagnieżdżonych) osiągnięto przedziały przedstawione w poniższej tabeli.

Tabela 5. Przedziały stopni specjalizacji produkcyjnej

\begin{tabular}{|l|l|l|l|l|}
\hline \multicolumn{1}{|c|}{$\begin{array}{c}\text { Stopień } \\
\text { specjalizacji }\end{array}$} & $\begin{array}{c}\text { Produkcja zwierzę- } \\
\text { ca (żywiec) }\end{array}$ & $\begin{array}{c}\text { Produkcja zwierzę- } \\
\text { ca (mleko krowie) }\end{array}$ & $\begin{array}{c}\text { Produkcja roślinna } \\
\text { (a) }\end{array}$ & $\begin{array}{c}\text { Produkcja roślinna } \\
\text { (b) }\end{array}$ \\
\hline wybitny & powyżej 0,70 & powyżej 12,9 & powyżej 0,82 & powyżej 0,63 \\
wysoki & $0,67-0,70$ & $6,4-12,9$ & $0,76-0,82$ & $0,58-0,63$ \\
\hline przeciętny & $0,61-0,66$ & $2,3-6,3$ & $0,67-0,75$ & $0,55-0,57$ \\
niski & poniżej 0,61 & poniżej 2,3 & poniżej 0,67 & poniżej 0,55 \\
\hline
\end{tabular}

Źródło: opracowanie własne.

Z uwagi na specyfikę przedmiotu badań istotnymi wynikami są wartości powyżej i poniżej wartości sr3. Wybitny stopień specjalizacji w produkcji żywca wykazują województwa lubuskie i zachodniopomorskie. Produkcję mleka krowiego, z racji wysokiej specjalizacji krajowej w tym zakresie, potraktowano osobno i przeanalizowano udział produkcji każdego z województw w produkcji krajowej. Wybitny stopień specjalizacji w produkcji mleka osiągnęły województwa: mazowieckie, podlaskie i wielkopolskie. W produkcji roślinnej (a) z kolei wybitny stopień specjalizacji odnotowano w kujawsko-pomorskim, opolskim i śląskim. W produkcji roślinnej (b) należy wyróżnić podlaskie i warmińsko-mazurskie, co świadczy także o profilu produkcji zwierzęcej (produkcja siana z łąk i pastwisk). Wysoki stopień specjalizacji produkcji zwierzęcej (żywiec) osiągnęło 5 województw, a w przypadku produkcji mleka krowiego - 3 województwa. Świadczy to o wysokiej specjalizacji produkcji krajowej. W przypadku produkcji roślinnej (a) 5 województw osiągnęło wysokie wskaźniki, natomiast dla produkcji roślinnej (b) - 3 województwa. Pozostałe województwa nie wykazują wartości wskazujących na specjalizację produkcyjną i osiągnęły wartości przeciętne oraz niskie.

Kierunki produkcji wskazano w tabeli 7. W przypadku produkcji mleka decydowała przeciętna wartość udziału w produkcji krajowej. Według przyjętej metody (Okuniewskiego) można było określić od 1 do 3 profilów produkcji w każdym rodzaju produkcji rolnej.

Specjalizacja produkcyjna województw zarówno w produkcji zwierzęcej, jak i roślinnej skupia się na kilku produktach. W przypadku tej pierwszej jest to żywiec wieprzowy lub drobiowy oraz mleko. Natomiast w produkcji roślinnej dominują owoce z drzew i warzywa gruntowe a także zboża podstawowe z mieszankami, buraki cukrowe oraz produkcja siana z łąk i pastwisk. Najbardziej wyspecjalizowane regiony pod względem produkcji (pomorskie i śląskie) nie wskazały żadnej specjalizacji inteligentnej związanej z sektorem rolnictwa. Wysoko wyspecjalizowane pod tym względem województwa, takie jak: podlaskie czy kujawsko-pomorskie wskazały aż po dwie specjalizacje inteligentne, lecz dysponują odpowiednio - niskim i średnim potencjałem rozwoju (patrz. tab. 4). Najwyższym potencjałem dysponuje województwo lubelskie, które specjalizuje się w produkcji żywca wieprzowego, owoców z drzew, warzywach gruntowych, zbożach i mieszankach oraz burakach cukrowych. W tym województwie jako specjalizację inteligentną wskazano biogospodarkę, 
co świadczy o wielokierunkowym rozwoju w ramach tej specjalizacji. Można przypuszczać, że sektor rolny nie będzie najważniejszym jej ogniwem, lecz jednym z kilku wspieranych w ramach jednej specjalizacji (województwo lubelskie wskazało łącznie 4 specjalizacje inteligentne).

Dla produkcji zwierzęcej analiza wykazała, że 8 województw ściśle specjalizuje się w jednym profilu produkcji (specjalizacja jednokierunkowa). W 5 województwach wykazano specjalizację dwukierunkową, natomiast w pozostałych 3 - brak jest specjalizacji produkcyjnej. Zupełnie odmienny wynik osiągnięto dla produkcji roślinnej, gdzie aż w 12 województwach występują więcej niż 2 dominujące kierunki produkcji. W województwach opolskim, podlaskim, śląskim i warmińsko-mazurskim określono dwukierunkowy typ specjalizacji.

Tabela 6. Specjalizacja produkcyjna wg wskaźnika specjalizacji rolniczej*

\begin{tabular}{|c|c|c|c|c|c|}
\hline Województwo & $\begin{array}{l}\text { Liczba } \\
\text { IS }\end{array}$ & $\begin{array}{l}\text { Produkcja zwie- } \\
\text { rzęca (żywiec) }\end{array}$ & $\begin{array}{l}\text { Produkcja zwie- } \\
\text { rzęca (mleko } \\
\text { krowie) }\end{array}$ & $\begin{array}{l}\text { Produkcja } \\
\text { roślinna (a) }\end{array}$ & $\begin{array}{l}\text { Produkcja } \\
\text { roślinna (b) }\end{array}$ \\
\hline Dolnośląskie & 1 & 0,70 & 1,5 & 0,79 & 0,55 \\
\hline Kujawsko-pomorskie & 2 & 0,64 & 7,2 & 0,88 & 0,54 \\
\hline Lubelskie & 1 & 0,63 & 6,1 & 0,61 & 0,56 \\
\hline Lubuskie & 1 & 0,78 & 0,7 & 0,71 & 0,57 \\
\hline Łódzkie & 1 & 0,61 & 7,6 & 0,67 & 0,57 \\
\hline Małopolskie & 1 & 0,57 & 2,5 & 0,79 & 0,58 \\
\hline Mazowieckie & 1 & 0,69 & 21,7 & 0,77 & 0,57 \\
\hline Opolskie & 1 & 0,66 & 2,1 & 0,86 & 0,60 \\
\hline Podkarpackie & 1 & 0,65 & 1,8 & 0,68 & 0,53 \\
\hline Podlaskie & 2 & 0,58 & 19,9 & 0,66 & 0,70 \\
\hline Pomorskie & 0 & 0,67 & 2,7 & 0,81 & 0,53 \\
\hline Śląskie & 0 & 0,67 & 1,9 & 0,84 & 0,60 \\
\hline Świętokrzyskie & 1 & 0,59 & 2,0 & 0,70 & 0,54 \\
\hline Warmińsko-mazurskie & 1 & 0,67 & 7,5 & 0,67 & 0,67 \\
\hline Wielkopolskie & 1 & 0,62 & 13,5 & 0,82 & 0,54 \\
\hline Zachodniopomorskie & 1 & 0,77 & 1,3 & 0,66 & 0,54 \\
\hline sr1 & - & 0,61 & 2,3 & 0,67 & 0,55 \\
\hline sr2 & - & 0,66 & 6,3 & 0,75 & 0,57 \\
\hline sr3 & - & 0,70 & 12,9 & 0,82 & 0,63 \\
\hline
\end{tabular}

*dla produkcji mleka przyjęto średnią wartość udziału w produkcji krajowej.

Źródło: opracowanie własne. 
Tabela 7. Rodzaje i profile produkcji rolnej - synteza

\begin{tabular}{|c|c|c|c|c|c|}
\hline \multirow{2}{*}{ Województwo } & \multirow{2}{*}{$\begin{array}{l}\text { Liczba } \\
\text { IS }\end{array}$} & \multicolumn{2}{|c|}{ Produkcja zwierzęca } & \multicolumn{2}{|c|}{ Produkcja roślinna } \\
\hline & & typ specjalizacji & profil produkcji & typ specjalizacji & profil produkcji \\
\hline Dolnośląskie & 1 & jednokierunkowa & drobiowy & brak specjalizacji & $\begin{array}{l}\text { warzywa gruntowe, zboża } \\
\text { podstawowe z mieszanka- } \\
\text { mi i łąki i pastwiska }\end{array}$ \\
\hline $\begin{array}{l}\text { Kujawsko- } \\
\text { pomorskie }\end{array}$ & 2 & jednokierunkowa & wieprzowy & brak specjalizacji & $\begin{array}{l}\text { warzywa gruntowe, zboża } \\
\text { podstawowe z mieszanka- } \\
\text { mi i buraki cukrowe }\end{array}$ \\
\hline Lubelskie & 1 & jednokierunkowa & wieprzowy & brak specjalizacji & $\begin{array}{l}\text { owoce z drzew i warzywa } \\
\text { gruntowe, zboża pod- } \\
\text { stawowe z mieszankami } \\
\text { i buraki cukrowe }\end{array}$ \\
\hline Lubuskie & 1 & jednokierunkowa & drobiowy & brak specjalizacji & $\begin{array}{l}\text { warzywa gruntowe, zboża } \\
\text { podstawowe z mieszanka- } \\
\text { mi i łąki i pastwiska }\end{array}$ \\
\hline Łódzkie & 1 & brak specjalizacji & $\begin{array}{l}\text { wieprzowy i dro- } \\
\text { biowy, mleko }\end{array}$ & brak specjalizacji & $\begin{array}{l}\text { owoce z drzew i warzywa } \\
\text { gruntowe, zboża podsta- } \\
\text { wowe z mieszankami i łąki } \\
\text { i pastwiska }\end{array}$ \\
\hline Małopolskie & 1 & dwukierunkowa & $\begin{array}{l}\text { wieprzowy } \\
\text { i drobiowy }\end{array}$ & brak specjalizacji & $\begin{array}{l}\text { warzywa gruntowe, zboża } \\
\text { podstawowe z mieszanka- } \\
\text { mi i łąki i pastwiska }\end{array}$ \\
\hline Mazowieckie & 1 & dwukierunkowa & drobiowy, mleko & brak specjalizacji & $\begin{array}{l}\text { owoce z drzew, zboża } \\
\text { podstawowe z mieszanka- } \\
\text { mi i łąki i pastwiska }\end{array}$ \\
\hline Opolskie & 1 & dwukierunkowa & $\begin{array}{l}\text { wieprzowy } \\
\text { i drobiowy }\end{array}$ & dwukierunkowa & $\begin{array}{l}\text { warzywa gruntowe, } \\
\text { zboża podstawowe } \\
\text { z mieszankami }\end{array}$ \\
\hline Podkarpackie & 1 & dwukierunkowa & $\begin{array}{l}\text { wieprzowy } \\
\text { i drobiowy }\end{array}$ & brak specjalizacji & $\begin{array}{l}\text { warzywa gruntowe, zboża } \\
\text { podstawowe z mieszanka- } \\
\text { mi i łąki i pastwiska }\end{array}$ \\
\hline Podlaskie & 2 & brak specjalizacji & $\begin{array}{l}\text { wieprzowy i dro- } \\
\text { biowy, mleko }\end{array}$ & dwukierunkowa & $\begin{array}{l}\text { warzywa gruntowe, łąki } \\
\text { i pastwiska }\end{array}$ \\
\hline Pomorskie & 0 & jednokierunkowa & wieprzowy & brak specjalizacji & $\begin{array}{l}\text { warzywa gruntowe, zboża } \\
\text { podstawowe z mieszanka- } \\
\text { mi i łąki i pastwiska }\end{array}$ \\
\hline Śląskie & 0 & jednokierunkowa & drobiowy & dwukierunkowa & $\begin{array}{l}\text { warzywa gruntowe, } \\
\text { zboża podstawowe } \\
\text { z mieszankami }\end{array}$ \\
\hline Świętokrzyskie & 1 & dwukierunkowa & $\begin{array}{l}\text { wieprzowy } \\
\text { i drobiowy }\end{array}$ & brak specjalizacji & $\begin{array}{l}\text { owoce z drzew, zboża } \\
\text { podstawowe z mieszanka- } \\
\text { mi i łąki i pastwiska }\end{array}$ \\
\hline $\begin{array}{l}\text { Warmińsko- } \\
\text {-mazurskie }\end{array}$ & 1 & jednokierunkowa & drobiowy & dwukierunkowa & $\begin{array}{l}\text { warzywa gruntowe, łąki } \\
\text { i pastwiska }\end{array}$ \\
\hline Wielkopolskie & 1 & brak specjalizacji & $\begin{array}{l}\text { wieprzowy i dro- } \\
\text { biowy, mleko }\end{array}$ & brak specjalizacji & $\begin{array}{l}\text { warzywa gruntowe, zboża } \\
\text { podstawowe z mieszanka- } \\
\text { mi i buraki cukrowe }\end{array}$ \\
\hline $\begin{array}{l}\text { Zachodnio- } \\
\text { pomorskie }\end{array}$ & 1 & jednokierunkowa & drobiowy & brak specjalizacji & $\begin{array}{l}\text { warzywa gruntowe, zboża } \\
\text { podstawowe z mieszanka- } \\
\text { mi i łąki i pastwiska }\end{array}$ \\
\hline
\end{tabular}

Źródło: opracowanie własne. 


\section{Podsumowanie i wnioski}

Analiza potencjałów pokazała, że samorządy adekwatnie do zasobów endogenicznych identyfikują specjalizacje inteligentne. W opozycji do tego stwierdzenia jednak staje wieloaspektowość tych specjalizacji, co wiąże się z istotnością sektora rolnego w polityce rozwoju opartej na specjalizacjach inteligentnych. Należy także mieć na uwadze, że struktura produkcji rolnej podlega zmianom, a działalność w ramach inteligentnych specjalizacji może te zmiany przyspieszyć. Popularność sektora rolnictwa w RIS napawa pewnymi nadziejami na postęp technologiczny. „Inteligentne specjalizowanie się” nie powinno w tym przypadku być ograniczane do innowacyjnych inicjatyw, lecz także do świadomego i zrównoważonego podejścia w planowaniu produkcji i jej odpowiedniej dywersyfikacji. Zróżnicowanie pomiędzy regionami w tym zakresie także jest relatywnie niskie i ogranicza się do 2-3 kierunków produkcji rolnej, zarówno zwierzęcej, jak i roślinnej. Wybitny bądź wysoki stopień specjalizacji produkcyjnej nie musi więc być zjawiskiem pozytywnym. Dywersyfikacja produkcji może okazać się pewnym zabezpieczeniem, lecz w dobie „specjalizowania się" staje się to mniej istotne. Taki stan rzeczy może okazać się zagrożeniem dla funkcjonowania gospodarstw rolnych o wysokiej monokulturze produkcji.

Niewiadomą pozostaje to, w jaki sposób nowa koncepcja rozwoju regionalnego wpłynie na rozwój rolnictwa. Wyspecjalizowane regiony mogą być wspierane w ramach specjalizacji inteligentnych we wskazanych kierunkach produkcji, lecz mogą się też utworzyć nowe kierunki i nowe możliwości. Polityka proinnowacyjna jest nastawiona na wdrażanie nowych technologii podnoszących konkurencyjność. Polskie rolnictwo może wykorzystać szansę, jaką daje nowa perspektywa finansowania, która ściślej niż w poprzednich latach ukierunkowuje działania inwestycyjne. Tradycyjne kierunki produkcji rolnej mają szansę dzięki tym działaniom, a ściślej - dzięki specjalizacjom inteligentnym, stać się bardziej konkurencyjne.

\section{Literatura}

Bański J., 1999, Obszary problemowe w rolnictwie Polski, Prace Geograficzne, 172, IGiPZ PAN, Warszawa.

Barca F., McCann P., Rodríguez-Pose A., 2012, The case for regional development intervention: place-based versus place-neutral approaches, Journal of Regional Science, 52 (1), s. 134-152.

Bathelt, H., Glückler J., 2012, Wirtschafts geographie. Ökonomische Beziehungen in räumlicher Perspektive, UTB, Stuttgart.

Benner M., 2013, From smart specialisation to smart experimentation: Towards a new theoretical framework for EU regional policy, SPACES online, 11, Issue 2013-04, Toronto and Heidelberg.

Bilbao-Osorio B., Rodríguez-Pose A., 2004, From R\&D to innovation and economic growth in the EU, Growth Change, 35 (4), s. 434-455.

Bowler I.R., 1986, Intensification, concentration and specialization in agriculture - the case of European Community, Geography, 71, s. 14-24

Bowler I.R., 1987, The regional restructuring of production in capitalist agriculture, Rural Systems, 5,1, s. $17-26$

Dziemianowicz W., Szlachta J., Peszat K., 2014, Potencjały rozwoju i specjalizacje polskich województw, Geoprofit, Warszawa. 
Dzierżanowski M., 2013, Definiowanie i rozwijanie inteligentnych specjalizacji - wnioski z dobrych praktyk w zakresie polityk klastrowych, Instytut Badań nad Gospodarką Rynkową, Gdańsk.

Foray D., 2009, Understanding "Smart Specialization" [w:] The Question of R\&D Specialization: Perspectives and policy implications, JRC Scientific and Technical Reports, European Commission, Bruksela.

Foray D., David P.A., Hall B., 2009, Smart Specialisation - The Concept, Knowledge Economists Policy Brief, 9, Bruksela

Grosse T.G., 2002, Przegląd koncepcji teoretycznych rozwoju regionalnego, Studia Regionalne i Lokalne, 1, Europejski Instytut Rozwoju Regionalnego i Lokalnego UW, Warszawa, s. 25-48

Kardas M., 2011, Inteligentna specjalizacja - (nowa) koncepcja polityki innowacyjnej, OPTIMUM STUDIA EKONOMICZNE, 2, Uniwersytet w Białymstoku, Białystok, s. 121-135

Kulikowski R., 2003, Syntetyczne metody badań produktywności i towarowości rolnictwa: Zastosowania w badaniach geograficznych w Polsce, Prace Geograficzne, 187, IGiPZ PAN, Warszawa.

Kulikowski R., 2012, Produktywność i towarowość rolnictwa w Polsce, Barometr Regionalny, 4 (30), WSZiA, Zamość, s. 17-29

McCann P., Ortega-Argiles R., 2015, Smart specialization, regional growth and applications to European Union cohesion policy, Regional Studies, 49, s. 1291-1302

Naldi L., Nilsson P., Westlund H., Wixe S., 2015, What is Smart Rural Development? Journal of Rural Studies, 40, s. 90-101

Okuniewski J., 1959, Intensywność i poziom produkcji w gospodarstwach chłopskich, PWRiL, Warszawa.

Okuniewski J., 1958, Próba oznaczenia kierunków produkcji, Zagadnienia Ekonomiki Rolnej, 1, IERiGŻ-PIB, Warszawa.

Pluta W., 1977, Wielowymiarowa analiza porównawcza w badaniach ekonomicznych, Państwowe Wydawnictwo Ekonomiczne, Warszawa.

Porter M.E., 1990, The Competitive Advantage of Nations, The Macmillan Press LTD, London.

Proniewski M., 2013, Badanie potencjałów i specjalizacji polskich regionów: zarys metodologiczny, Ministerstwo Rozwoju Regionalnego, Warszawa (ekspertyza).

Pytkowski W., 1964, Niektóre pojęcia z zakresu organizacji gospodarstw, Zagadnienia Ekonomiki Rolnej, 4, s. 165-169

Raport o stanie środowiska w województwie podkarpackim w 2010 roku, 2011, Biblioteka Monitoringu Środowiska, Rzeszów.

Rehfeld D., 2013, Clusterpolitik, intelligente Spezialisierung, soziale Innovationen - neue Impulse in der Innovationspolitik, IAT Forschung Aktuell, 04, Institut Arbeit und Technik der Westfälischen Hochschule, Gelsenkirchen, Bocholt, Recklinghausen.

Rodrígues-Pose A., 2001, Is R\&D investment in lagging areas of Europe worthwhile? theory and empirical evidence, Papers in Regional Science, 80 (3), s. 275-295.

Ślusarz G., 2015, Koncepcja inteligentnej specjalizacji w rolnictwie i obszarach wiejskich. Dylematy i wyzwania. Roczniki Naukowe SERiA, XVII, 6, Poznań.

Szyrmer J.H., 1975, Stopień specjalizacji rolnictwa, Próba zastosowania nowej metody mierzenia, Przegląd Geograficzny, 47, 1, s. 117-135

Tłuczak A., 2016, Regionalna specjalizacja produkcji rolnej w Polsce, Studia Obszarów Wiejskich, 42 , s. 209-216.

Wojtaszek Z., 1963, Zagadnienia specjalizacji gospodarstw rolnych w Wielkiej Brytanii, Zagadnienia Ekonomiki Rolnej, 6, Warszawa, s. 101-116 
Vanthillo T., Verhetsel A., 2012, Paradigm change In regional policy: towards smart specialisation? Lessons from Flanders (Belgium), Belgeo, 1-2, Inaugural issue, s. 5. www.bdl.stat.gov.pl/bdl/start www.minrol.gov.pl

\section{Summary}

The article presents analysis of development potential of agriculture in Poland in regional dimension in the context of smart specializations concept. The paper assumed to characterize all smart specializations related to agriculture. The analysis of all 16 voivodships in the context of agriculture potential was conducted. Three potentials: economic, natural and scientific were examined. In addition, the research has been extended to identify production specialization in each region. Numerous statistical methods were used in the studies and classification of development potential was conducted in the context of implementing regional smart specializations. The objectives of the Europe 2020 Strategy extend regional policy to develop Regional Innovation Strategies, where regions are obligated to identify their strengths. This is important in the context of the new funding program of 2014-2020, as the initiatives supported by the RIS are to implement in all voivodships an innovative model of economic development. However, the choice of smart specialization does not always reflect the real potential of the region in a given sector. The agricultural sector is also specific due to many constraints, therefore the total output potential is incomparable between regions. 


\section{Informacja dla Autorów}

Studia Obszarów Wiejskich to wydawnictwo publikujące oryginalne opracowania naukowe z zakresu geografii społeczno-ekonomicznej, geografii wsi i przestrzennego zagospodarowania kraju w języku polskim lub/i angielskim. Zapraszamy Autorów do nadsyłania wartościowych artykułów. Przestrzeganie poniższych zaleceń formalnych usprawni prace redakcyjne i przyczyni się do szybszej publikacji nadsyłanych materiałów.

Uwagi ogólne. Zgłoszenie przez autora (ów) tekstu do Studiów Obszarów Wiejskich oznacza, że nie jest on przewidziany do druku w innym wydawnictwie. Jest także jednoznaczne z wyrażeniem zgody na jego rozpowszechnianie przez IGiPZ PAN w formie drukowanej i elektronicznej z wykorzystaniem licencji Creative Commons: uznanie autorstwa, 3.0 Polska.

Podstawowym sposobem przekazania materiałów do druku jest przesłanie tekstu i załączników na płycie CD na adres wskazany przez redakcję. Tekst artykułu powinien być napisany zwięźle, ale jasno, przy użyciu edytora MS WORD. Objętość artykułu nie powinna przekraczać 6000 słów. Wszystkie załączniki graficzne muszą być dostarczone w formie osobnych plików. Preferowany format dla danych liczbowych to MS EXCEL, a dla załączników graficznych pliki w formacie JPG, TIF, EPS, CDR*, AL* (*Wymagany zapis do edycji w starszych wersjach programów, na chwilę obecną: Corel Draw do wersji 14, Adobe llustrator do wersji 11).

Strona tytułowa. Na pierwszej stronie należy w kolejności umieścić: tytuł pracy w języku polskim, tytuł pracy w języku angielskim, imię i nazwisko autora/autorów (cyfry arabskie po nazwisku, umieszczane jako indeks górny, określają odp. afiliację), afiliację, adres (y), e-mail (e), zarys treści (maksymalnie 200 słów powinien zawierać: sformułowanie celu pracy/badań, identyfikację obiektu badań, przedmiotu rozważań, istotę stosowanej metody, najważniejsze wyniki i wnioski), słowa kluczowe (podaje się nie więcej niż 5 słów kluczowych).

Tekst artykułu pisany czcionką Calibri Light 10, interlinia 1,0. Nie należy nadawać odrębnych stylów znakowych i akapitowych oraz specyficznych wyróżnień (kolor, podkreślenia, itd.) fragmentom tekstu. W tekście opracowania, przy powoływaniu się na literaturę, należy podawać nazwisko autora oraz rok publikacji, np. (Nowak 2004; Kowalski 2005, 2007) lub według A. Nowaka (2006), a przy cytowaniu również numer strony, np. według A. Nowaka $(2006$, s. 6). W powołaniach na więcej prac tego samego autora, które ukazały się w tym samym roku, podaje się: (Nowak 1987a, b). W przypadku wspólnej publikacji dwóch autorów podaje się: (Kowalski i Nowak 1999), a trzech i więcej autorów: (Kowalski i in. 2006).

Podziękowania - opcjonalnie oraz ewentualna informacja o źródłach finansowania publikacji i wkładzie innych podmiotów w opracowanie publikacji (zgodnie z wymogami jakościowymi i standardami etycznymi opisanymi niżej) należy zamieścić po zasadniczym tekście.

Rysunki i fotografie z podpisami i objaśnieniami w j. polskim i angielskim powinny być zamieszczone w tekście, a ponadto dołączone w postaci osobnych plików posiadających numerację zastosowaną w tekście. Wymagana jest wysoka rozdzielczość rysunków i fotografii (min. 300 dpi w plikach rastrowych JPG lub TIF). Dopuszczalne formaty wektorowe (EPS, Al*, CDR*). Tytuł ryciny i źródło w języku polskim i angielskim powinny znajdować się poza rysunkiem, w pliku tekstowym. Objaśnienia znaków legendy w języku polskim i angielskim można zamieścić w obrębie ryciny lub poza nią. Rysunki i fotografie drukowane są w kolorze czarno-białym. Należy upewnić się, że po zastąpieniu ew. kolorów skalą szarości i przeskalowaniu do rozmiarów maksymalnie 12,5 x $20 \mathrm{~cm}$ będą one wystarczająco czytelne. Zalecany krój czcionki dla napisów będących częścią grafiki (bez możliwości edycji) to Calibri.

Tabele powinny być zamieszczone w tekście. Każda tabela powinna zawierać zwięzły tytuł (u góry) w języku polskim, kolejny numer i źródło danych (u dołu). Wszystkie skróty powinny być objaśnione (tytuł, źródło i objaśnienia należy dołączyć jedynie w pliku tekstowym). W komórkach tabeli nie powinny znajdować się znaki tabulacji (Tab) ani końca akapitu (Enter) - w razie potrzeby można korzystać ze znaku wymuszonego końca wiersza (Shift+Enter). Należy unikać nietypowego formatowania (jak wypełnienia kolorystyczne komórek, różne grubości linii, itd.).

Spis literatury ograniczony do literatury cytowanej, w porządku alfabetycznym, należy zamieścić poniżej tekstu artykułu według poniższego wzoru:

Artykuły w czasopismach i seriach wydawniczych:

Wójcik M., 2011, Współczesne kierunki i podejścia badawcze w geografii wsi, Przegląd Geograficzny, 83, 2, s. $163-185$.

Kulikowski R., 2013, Obszary wiejskie województwa podlaskiego w perspektywie 2050 roku, Studia Obszarów Wiejskich, 31, s. 129-142.

Rozdziały w pracach zbiorowych:

Zegar J.S., 2014, Typy społeczno-ekonomiczne indywidualnych gospodarstw rolnych według rodzaju gmin, [w:] R. Rudnicki. M. Kluba (red.), Zintegrowany rozwój obszarów wiejskich w świetle polityki Unii Europejskiej, t. 1, Rolnictwo i Wspólna Polityka Rolna, Wydawnictwo Naukowe Uniwersytetu Mikołaja Kopernika, Toruń, s. $57-73$.

Książki

Bański J., 2006, Geografia polskiej wsi, PWE, Warszawa. 
Streszczenie. Na końcu opracowania powinno być zamieszczone streszczenie w języku angielskim zweryfikowane przez native-speakera. Objętość streszczenia: około 250-400 słów.

Ocena artykułów i dopuszczenie ich do druku. Wszystkie artykuły niespełniające powyższych zasad będą odsyłane do poprawy. Artykuły podlegają ocenie przez dwóch recenzentów. W procesie recenzowania stosowane jest rozwiązanie, w którym autor (zy) i recenzenci nie znają swoich tożsamości (tzw. „double-blind review proces").Wynik recenzji będzie miał decydujący wpływ na możliwość opublikowania materiału w Studiach Obszarów Wiejskich.

Zasady dotyczące recenzowania w Studiach Obszarów Wiejskich

1. Do oceny każdej publikacji powołuje się co najmniej dwóch niezależnych recenzentów spoza jednostki, w której afiliowani są autorzy publikacji.

2. W przypadku tekstów powstałych w języku obcym, co najmniej jeden z recenzentów jest afiliowany w instytucji zagranicznej innej niż narodowość autora pracy.

3. W procesie recenzowania stosowane jest rozwiązanie, w którym Autor(zy) i recenzenci nie znają swoich tożsamości (tzw. double-blind review proces).

4. Wyznaczając recenzentów redakcja wydawnictwa zachowuje ponadto zasadę zapobiegania konfliktom interesów między recenzentem a autorem.

5. Recenzje mają formę pisemną i kończą się jednoznacznym wnioskiem do dopuszczenia artykułu do publikacji lub jego odrzucenia, względnie warunkowego dopuszczenia tekstu do publikacji po jego poprawieniu przez autora według uwag zawartych w recenzji. W takiej sytuacji recenzent może zastrzec sobie prawo do ponownego zrecenzowania pracy, po dokonaniu przez autora poprawek wskazanych w pierwszej recenzji. Do publikacji dopuszczane będą prace posiadające dwie pozytywne recenzje (zawierające wniosek o dopuszczenie do publikacji) - wzór recenzji poniżej.

6. Zasady kwalifikowania lub odrzucenia publikacji oraz formularz recenzji są podane do publicznej wiadomości na stronie internetowej wydawnictwa.

7. Nazwiska recenzentów nie są publikowane przy poszczególnych artykułach

Studia Obszarów Wiejskich

ARKUSZ RECENZII

Tytuł recenzowanego artykułu

1. Czy zagadnienie przedstawione w artykule jest istotne pod względem naukowym i może zainteresować szersze grono czytelników? Czy praca przedstawia oryginalne materiały autorskie, stanowi syntezę czy przegląd badań?

2. Czy tematyka artykułu odpowiada tematyce tomu i profilowi Studiów Obszarów Wiejskich?

3. Czy sposób przedstawienia tematu jest prawidłowy, to znaczy (odpowiedź: Tak lub Nie)

- czy tytuł dokładnie odpowiada treści?

- czy zagadnienie zostało przedstawione w sposób logiczny?

- czy wnioski wynikają z treści pracy?

- czy odpowiednie pozycje literatury zostały uwzględnione?

- czy ilustracje (tabele wykresy, mapy) są czytelne i wystarczające

4. Sugerowane poprawki (rozwinięcie na odwrotnej lub osobnej stronie). Drobne poprawki mogą być zaznaczone w tekście artykułu.

\section{WNIOSEK:}

Ocena artykułu:

Bardzo dobra

$\square$ Dobra

口 Przeciętna

口 Temat interesujący, ale słabo przedstawiony

Artykuł warto opublikować (właściwe podkreślić):

- w wersji przedstawionej przez autora (-ów)

- z ewentualnymi drobnymi poprawkami sugerowanymi przez recenzentów i/lub redakcję

- po dokonaniu zasadniczych zmian sugerowanych przez recenzentów i redakcję

- artykuł nie nadaje się do publikacj

Wymogi jakościowe i standardy etyczne. W trosce o dochowanie najwyższych standardów redakcyjnych oraz w celu zapobieżenia nierzetelności w publikacjach naukowych określanych jako tzw. ghostwriting i guest authorship Redakcja Studiów Obszarów Wiejskich wymaga od autorów ujawniania informacji o podmiotach przyczyniających się do powstania publikacji (wkład merytoryczny, rzeczowy, finansowy etc.). W tym celu zobowiązuje się autorów do zachowania następujących standardów podczas przygotowywania tekstów składanych do publikacji: 1) w przypadku publikacji naukowych, które nie zostały wykonane samodzielnie, tzn. opracowano je we współautorstwie lub z wykorzystaniem pomocy wyspecjalizowanego podmiotu (osoby fizycznej lub praw- 
nej), w końcowej części pracy (w punkcie: „Podziękowania”) należy zawrzeć notę, w której ujawniany jest wkład poszczególnych autorów (współautorów) w powstanie publikacji (artykułu, monografii). Oznacza to konieczność podania ich afiliacji oraz kontrybucji, tj. informacji kto jest autorem koncepcji, założeń, zastosowanych metod, protokołu itp., wykorzystywanych w toku pracy badawczej - przygotowywania publikacji; główną odpowiedzialność ponosi autor zgłaszający manuskrypt. 2) Autor/współautorzy podają ponadto informację o ewentualnych źródłach finansowania publikacji, wkładzie instytucji naukowo-badawczych, stowarzyszeń i innych podmiotów w opracowanie publikacji (financial disclosure). Redakcja wydawnictwa informuje, że wszelkie przejawy nierzetelności naukowej, zwłaszcza łamania i naruszania zasad etyki obowiązujących w nauce, w tym wykryte przypadki ghostwriting, guestauthorship będą dokumentowane i oficjalnie demaskowane, włącznie z powiadomieniem odpowiednich podmiotów (instytucje zatrudniające autorów, towarzystwa naukowe, stowarzyszenia edytorów naukowych itp.).

Z ghostwriting mamy do czynienia wówczas, gdy ktoś wniósł istotny wkład w powstanie publikacji, bez ujawniania swojego udziału jako jeden z autorów lub bez wymieniania jego roli w Podziękowaniach zamieszczonych w publikacji.

Z guest authorship (honorary autorship) mamy do czynienia wówczas, gdy udział autora jest znikomy lub w ogóle nie miał miejsca, a pomimo to jest autorem/wspłautorem publikacji.

Wersja pierwotna. Wersja papierowa i elektroniczna są tożsame, jednakże Redakcja wskazuje wersję papierową jako wersję pierwotną czasopisma.

\section{Adres Redakcji}

ul. Twarda 51/55, 00-818 Warszawa

tel. (+48 22) 69788 34, fax (+48 22) 6206221

e-mail: b.solon@twarda.pan.pl

Redaktor Naczelny Studiów Obszarów Wiejskich 